Original Research Article

\title{
Randomized controlled trial of rectal misoprostal and intramuscular oxytocin in the prevention of PPH
}

\author{
Savitha A. ${ }^{1}$, Sarita H. ${ }^{1 *}$, Kashinath Gumma ${ }^{2}$
}

${ }^{1}$ Department of Obstetrics and Gynecology, ${ }^{2}$ Department of Pharmacology, BRIMS, Bidar, Karnataka, India

Received: 07 March 2017 Accepted: 03 April 2017

*Correspondence to:

Dr. Savitha A.,

Email:

drsavitha96@rediffmail.com

Copyright: (C) the author(s), publisher and licensee Medip Academy. This is an openaccess article distributed under the terms of the Creative Commons Attribution NonCommercial License, which permits unrestricted noncommercial use, distribution, and reproduction in any medium, provided the original work is properly cited.

\begin{abstract}
Background: PPH accounts for merely $23 \%$ of maternal mortality in developing countries. Misoprostol is a uterotonic agent and is a PGE analogue commonly used in management of PPH. Oxytocin is another uterotonic agent which is now been introduced as intramuscularly effective agent to prevent PPH.This study aims to compare rectal misoprostol with intramuscular oxytocin in reducing blood loss in third stage of labor to prevent PPH. Objective of present study is to compare the clinical effect of rectal misoprostol with intramuscular oxytocin in prevention of PPH.

Methods: A randomized study was conducted over duration of 3 months, at Department of OBG, BRIMS, Bidar, Karnataka, India. Patients with singleton pregnancy with the history of one previous LSCS and opting for elective LSCS were included in the study. Patients with risk pregnancy, such as pre eclampsia, cardiac disease and asthma or grand multipara were excluded from the study. Immediately after spinal anesthesia rectal misoprostol was given while oxytocin was administered after delivery of the baby. Incidence of PPH and amount of blood loss was observed and compared.

Results: The difference in both the groups with regard to mean amount of blood loss, mean duration of the third stage of labor, and mean amount of fall in hemoglobin level was not statistically significant as $\mathrm{P}$ value was $>0.05$. The incidence of PPH and the need for additional oxytocic are slightly more in the misoprostol group. The incidence of shivering and pyrexia was more in the misoprostol group, but not so disturbing so as to lead to disuse of this drug.

Conclusions: Oral misoprostol, though not a replacement of parenterally administered oxytocin, can be used safely in all deliveries for the prevention of postpartum hemorrhage.
\end{abstract}

Keywords: Misoprostol, Oxytocin, PPH

\section{INTRODUCTION}

Postpartum hemorrhage (PPH) is a life-threatening obstetric emergency that occurs after caesarean section (CS) or normal vaginal delivery (NVD). It may be defined as $\geq 500 \mathrm{~mL}$ hemorrhage after vaginal or $\geq 1000 \mathrm{~mL}$ hemorrhage after CS delivery. ${ }^{1-3}$ In India, the maternal mortality rate is $212 / 1,00,000$ live births and $\mathrm{PPH}$ is responsible for $25 \%$ of deaths. PPH is not only responsible for maternal mortality, but also causes morbidity known as severe acute maternal morbidity (SAMM) including anemia, pituitary necrosis, shock, hysterectomy, loss of fertility. Atony is the main cause of $\mathrm{PPH}$ and is responsible for about $80 \%$ of PPHs. ${ }^{4}$
Therefore, uterotonic agents are administered. Oxytocin infusion, single dose of methylergometrine, and then carboprost tromethamine are used in 15-to-20-minute intervals in atony. Misoprostol, which is a prostaglandin $\mathrm{E} 1$ analog, is an inexpensive drug and can be absorbed by the following routes of administration: vaginal, rectal, or oral (sublingual or buccal absorption). ${ }^{5,6}$ Gastrointestinal symptoms (nausea, vomiting, and diarrhea) and fever are the most common adverse effects of misoprostol, which often are mild and self-limited. ${ }^{7-10}$

AMTSL includes the Administration of oxytocin or another uterotonic drug just after birth of the baby, Controlled cord traction, and uterine massage. ${ }^{1}$ 
Misoprostol is a oxytocic drug easily available, has the safest route of administration, needs no storage condition, is inexpensive, and has a long shelf life and a positive safely profile, making it a good option in resource-poor settings for AMTSL. ${ }^{11,12}$

\section{METHODS}

The present study was conducted in the Department of Obstetrics and Gynaecology, Bidar Institute of Medical Sciences, Bidar, in the period of 3 months from august 2015 to October 2015 two hundred pregnant women between 37 to 40 weeks gestation history of 1 previous LSCS were selected. Women with eclampsia, asthma, epilepsy, heart disorder, kidney disorder, and coagulation disorders were excluded from the study. All selected women were randomly divided into two equal groups (100 each). In the Misoprostol group, women were given $600 \mathrm{mcg}$ of rectal misoprostol immediately after spinal anesthesia. Similarly, in the oxytocin group, women were given intramuscular oxytocin $10 \mathrm{IU}$ immediately after the extraction of baby. In both the groups, pulse rate and blood pressure were recorded both before and after the third stage of labor. The amount of blood loss (in ml) was estimated by calibrated plastic blood collection drape in which blood was collected after drainage of liquor and extraction of the baby and was continued until the third stage of labor was completed. The duration of the third stage of labor was noted (in minutes). Hemoglobin measurement was done both at the time of admission and at the time of discharge by means of Sahli's haemoglobinometer. Side effects such as abdominal pain, nausea, vomiting, diarrhea, shivering, and pyrexia were recorded. If any signs of excessive blood loss appeared, other uterotonics such as methylergometrine or carboprost were given immediately in both the cases. Statistical analysis was carried out using the student t test. The difference among groups was considered to be significant at $\mathrm{P}<0.05$.

\section{RESULTS}

Table 1: Socio-demographic pattern.

\begin{tabular}{|lll|}
\hline Factors & $\begin{array}{l}\text { Misoprostol } \\
\text { group N=100 }\end{array}$ & $\begin{array}{l}\text { Oxytocin } \\
\text { group N=100 }\end{array}$ \\
\hline Age (years) & & \\
\hline $19-24$ & 48 & 48 \\
\hline $25-36$ & 52 & 52 \\
\hline Parity & \\
\hline Previous LSCS & 100 & 100 \\
\hline Socioeconomic class & \\
\hline High middle & 4 & 2 \\
\hline Lower middle & 56 & 62 \\
\hline Lower class & 40 & 36 \\
\hline
\end{tabular}

Among the 200 women enrolled in the study, 100 subjects received oral misoprostol, while 100 subjects received intramuscular oxytocin.
Mean age, parity, and socioeconomic status were comparable in both the groups (Table 1). The outcome data are shown in (Table 2).

The mean blood loss in the misoprostol group was $145 \mathrm{ml}$ and in the oxytocin group was $125.6 \mathrm{ml}$. The difference was not statistically significant $(\mathrm{P}<0.05)$.

Table 2: Distribution of cases according to the outcome of the study.

\begin{tabular}{|llll|}
\hline Outcome & $\begin{array}{l}\text { Misoprostol } \\
\text { group (N) }\end{array}$ & $\begin{array}{l}\text { Oxytocin } \\
\text { group (N) }\end{array}$ & $\begin{array}{l}\text { P } \\
\text { value }\end{array}$ \\
\hline $\begin{array}{l}\text { Mean amount of } \\
\text { blood loss } \\
\text { (in ml) }\end{array}$ & 145 & 125.6 & $>0.05$ \\
\hline $\begin{array}{l}\text { Mean duration of } \\
\text { third stage of } \\
\text { labor (in min) }\end{array}$ & 3.76 & 3.50 & $>0.05$ \\
\hline $\begin{array}{l}\text { Mean amount of } \\
\text { fall in hemoglobin } \\
\text { level (gm/d) }\end{array}$ & 0.55 & 0.48 & $>0.05$ \\
\hline \begin{tabular}{l}
$\mathrm{N}=100$ \\
\hline
\end{tabular} & & & \\
\hline
\end{tabular}

Mean duration of the third stage of labor in the misoprostol group was $3.76 \mathrm{~min}$ and in the oxytocin group was $3.50 \mathrm{~min}(\mathrm{P}<0.05)$.

Mean amount of fall in hemoglobin level in the misoprostol group was $0.55 \mathrm{~g} / \mathrm{dl}$ and in the oxytocin group was $0.48 \mathrm{~g} / \mathrm{dl}(\mathrm{P}<0.05)$. In the misoprostol group, 8 women and in the oxytocin group, 6 women had PPH.

Table 3: Distribution of cases according to the occurrence of PPH and need of additional oxytocic.

\begin{tabular}{|lll|}
\hline Outcome & $\begin{array}{l}\text { Misoprostol } \\
\text { group N=100 }\end{array}$ & $\begin{array}{l}\text { Oxytocin } \\
\text { group N=100 }\end{array}$ \\
\hline Occurrence of PPH & 8 & 6 \\
\hline $\begin{array}{l}\text { Need of additional } \\
\text { oxytocic }\end{array}$ & 22 & 16 \\
\hline Normal & 70 & 78 \\
\hline
\end{tabular}

Table 3: Distribution of cases according to side effects.

\begin{tabular}{|lll|} 
Outcome & $\begin{array}{l}\text { Misoprostol } \\
\text { group N=100 }\end{array}$ & $\begin{array}{l}\text { Oxytocin } \\
\text { group N=100 }\end{array}$ \\
\hline Shivering & 50 & 08 \\
\hline Pyrexia & 06 & 02 \\
\hline Abdominal pain & 26 & 22 \\
\hline Diarrhea & 10 & 00 \\
\hline Nausea & 08 & 08 \\
\hline Vomiting & 04 & 02 \\
\hline
\end{tabular}

Twenty-two women in the misoprostol group and 16 in the oxytocin group required additional oxytocic (Table 3). Side effects like shivering and pyrexia were more in the misoprostol group (Table 4). 


\section{DISCUSSION}

The third stage of labor is a crucial period where negligence can turn a previously uneventful pregnancy into a disaster. The role of oxytocics is to stimulate myometrial contraction, the major factor reducing the third stage bleeding. The aim of the present study was to evaluate the role of misoprostol in active management of the third stage of labor and compare it with oxytocin. In our study, a maximum number of patients in both the groups were in the age group of $18-24$ years, $52 \%$ in both groups. The maximum number of patients in both groups belonged to the lower middle class. The difference in both the groups with regard to mean amount of blood loss, mean duration of the third stage of labor, and mean amount of fall in hemoglobin level was not statistically significant as $P$ value was $>0.05$. Similar results were obtained in the study of Oboro and Tabowie. ${ }^{4}$ The incidence of PPH and the need for additional oxytocic are slightly more in the misoprostol group. The incidence of shivering and pyrexia was more in the misoprostol group, but not so disturbing so as to lead to disuse of this drug. ${ }^{5,6}$

\section{CONCLUSION}

Oral misoprostol, though not a replacement of parenterally administered oxytocin, can be used safely in all deliveries for the prevention of postpartum hemorrhage.

\section{ACKNOWLEDGEMENTS}

The authors would like to express their thanks to professors and other staff members of Obstetrics and Gynaecology Department for permitting us to conduct the study. Authors would also like to express their gratitude to other staff members of department of pharmacology for their constant support

Funding: No funding sources Conflict of interest: None declared

Ethical approval: The study was approved by the Institutional Ethics Committee

\section{REFERENCES}

1. Andolina K, Daly S, Roberts N, Tolosa J, Wapner R. Objective measurement of blood loss at delivery. Is it more than a guess? Am J Obstet Gynecol. 1999;180:S69.

2. Stafford I, Dildy GA, Clark SL, Belfort MA. Visually estimated and calculated blood loss in vaginal and cesarean delivery. Am J Obstet Gynecol. 2008;199:519.

3. Dildy GA. Postpartum hemorrhage: new management options. Clin Obstet Gynecol. 2002;45(2):330-44.

4. Oboro VO, Tabowei TO. A randomized controlled trial of misoprostol versus oxytocin in the active management of the third stage of labour. J Obstet Gynaecol. 2003;23:13-6.

5. Zieman M, Fong SK, Benowitz NL, Banskter D, Darney PD. Absorption kinetics of misoprostolwith oral or vaginal administration. Obstet Gynecol. 1997;90(1):88-92.

6. Arvidsson C, Hellborg M, Gemzell-Danielsson K. Preference and acceptability of oral versus vaginal administration of misoprostol in medical abortion with mifepristone. Eur J Obstet Gynecol Reprod Biol. 2005;123(1),87-91.

7. Winikoff B, Dabash R, Durocher J, Darwish E, Nguyen TN, León W et al. Treatment of post-partum haemorrhage with sublingual misoprostol versus oxytocin in women not exposed to oxytocin during labour: a double-blind, randomized, non-inferiority trial. Lancet. 2010;375:210-6.

8. Derman RJ, Kodkany BS, Goudar SS, Geller SE, Naik VA, Bellad MB et al. Oral misoprostol in preventing postpartum haemorrhage in resource-poor communities: a randomized controlled trial. Lancet. 2006;368:1248-53.

9. Alfirevic Z, Blum J, Walraven G, Weeks A, Winikoff B. Prevention of postpartum hemorrhage with misoprostol. Int J Gynecol Obstet. 2007;99:198-201.

10. Chong YS, Chua S, Arulkumaran S. Severe hyperthermia following oral misoprostol in the immediate postpartum period. Obstet Gynecol. 1997;90(4)703-4.

11. Gulmezoglu AM, Villar J, Ngoc NT, Piaggio G, Carroli G, Adetoro L et al. WHO multicentre randomized trial of misoprostol in the management of the third stage of labour. Lancet. 2001;358:689-95.

12. Blum J, Winikoff B, Raghavan S, Dabash R, Ramadan MC, Dilbaz B. Treatment of post-partum haemorrhage with misoprostol versus oxytocin in women receiving prophylactic oxytocin: a doubleblind, randomized, noninferiority trial. Lancet. 2010;375:217-23.

Cite this article as: Savitha A, Sarita H, Gumma K. Randomized controlled trial of rectal misoprostal and intramuscular oxytocin in the prevention of PPH. Int J Basic Clin Pharmacol 2017;6:1101-3. 